Published in final edited form as:

Am J Reprod Immunol. 2018 June ; 79(6): e12820. doi:10.1111/aji.12820.

\title{
Innate Lymphoid Cells at the Human Maternal-Fetal Interface In Spontaneous Preterm Labor
}

\author{
Yi Xu ${ }^{1,2}$, Roberto Romero ${ }^{1,3,4,5}$, Derek Miller ${ }^{1,2,6}$, Pablo Silva ${ }^{1,7}$, Bogdan Panaitescu ${ }^{1,2}$, \\ Kevin R Theis ${ }^{1,2,6}$, Afrah Arif ${ }^{2}$, Sonia S Hassan ${ }^{1,2}$, and Nardhy Gomez-Lopez ${ }^{1,2,6}$ \\ ${ }^{1}$ Perinatology Research Branch, Division of Obstetrics and Maternal-Fetal Medicine, Division of \\ Intramural Research, Eunice Kennedy Shriver National Institute of Child Health and Human \\ Development, National Institutes of Health, U S Department of Health and Human Services, \\ Bethesda, Maryland, and Detroit, Michigan, USA \\ ${ }^{2}$ Department of Obstetrics and Gynecology, Wayne State University School of Medicine, Detroit, \\ Michigan, USA \\ ${ }^{3}$ Department of Obstetrics and Gynecology, University of Michigan, Ann Arbor, Michigan, USA \\ ${ }^{4}$ Department of Epidemiology and Biostatistics, Michigan State University, East Lansing, \\ Michigan, USA \\ ${ }^{5}$ Center for Molecular Medicine and Genetics, Wayne State University, Detroit, Michigan, USA \\ ${ }^{6}$ Department of Immunology, Microbiology and Biochemistry, Wayne State University School of \\ Medicine, Detroit, Michigan, USA \\ ${ }^{7}$ Division of Obstetrics and Gynecology, Faculty of Medicine, Pontificia Universidad Católica de \\ Chile, Santiago, Chile
}

\begin{abstract}
Problem-Pathological inflammation is causally linked to preterm labor and birth, the leading cause of neonatal morbidity and mortality worldwide. Our aims were to investigate whether: 1) the newly described family of innate lymphoid cells (ILCs) was present at the human maternal-fetal interface, and 2) ILC inflammatory subsets were associated with the pathological process of preterm labor.
\end{abstract}

Methods of Study-Decidual leukocytes were isolated from women with preterm or term labor as well as from gestational age-matched non-labor controls. ILCs (CD15-CD14-CD3-CD19-CD56-CD11b-CD127+ cells) and their subsets (ILC1, Tbet+ILCs; ILC2, GATA3+ILCs; and ILC3, ROR $\gamma \mathrm{t}+\mathrm{ILCs})$ and cytokine expression were identified in the decidual tissues using immunophenotyping.

Address correspondence to: Nardhy Gomez-Lopez, MSc, PhD, Department of Obstetrics and Gynecology, Wayne State University School of Medicine, Perinatology Research Branch, NICHD/NIH/DHHS, 275 E. Hancock, Detroit, Michigan 48201, USA, Tel (313) 577-8904, nardhy.gomez-lopez@wayne.edu.

DR ROBERTO ROMERO (Orcid ID : 0000-0002-4448-5121)

DR NARDHY GOMEZ-LOPEZ (Orcid ID : 0000-0002-3406-5262)

Conflict of Interest Statement: The authors declared no potential conflicts of interest. 
Results-1) The proportion of total ILCs was increased in the decidua parietalis of women with preterm labor; 2) ILC1s were a minor subset of decidual ILCs during preterm and term gestations; 3) ILC2s were the most abundant ILC subset in the decidua during preterm and term gestations; 4) the proportion of ILC2s was increased in the decidua basalis of women with preterm labor; 5) the proportion of ILC3s was increased in the decidua parietalis of women with preterm labor; and 6) during preterm labor, decidual ILC3s had higher expression of IL-22, IL-17A, IL-13, and IFN $\gamma$ compared to ILC2s.

Conclusions-ILC2s are the most abundant ILC subset at the human maternal-fetal interface during preterm and term gestations. Yet, during preterm labor, an increase in ILC2s and ILC $3 \mathrm{~s}$ is observed in the decidua basalis and decidua parietalis, respectively. These findings provide evidence demonstrating a role for ILCs at the maternal-fetal interface during the pathological process of preterm labor.

\section{Graphical abstract}

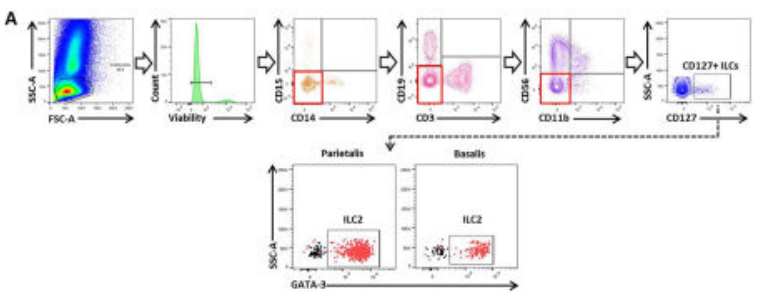

\section{Keywords}

Inflammation; Pregnancy; Decidua; Parturition; Interleukin; Cytokine; Innate Immunity; Tolerance; Mucosal Immunity

\section{Introduction}

Preterm birth, defined as birth prior to 37 weeks of gestation, is one of the most common obstetrical syndromes ${ }^{1-3}$ and the leading cause of perinatal morbidity and mortality worldwide $^{4-8}$. In 2013, 11.39\% of all births in the United States were diagnosed as preterm ${ }^{9}$. Premature neonates are at an increased risk for short- and long-term morbidities which represent a substantial burden for society and the healthcare system ${ }^{10-13}$. Approximately $70 \%$ of all preterm births are preceded by spontaneous preterm labor ${ }^{1,14}$, with multiple pathological processes involved ${ }^{15}$. Therefore, it is essential to determine the mechanisms implicated in spontaneous preterm labor and to develop novel therapies and strategies to prevent this syndrome.

Inflammation is implicated in the pathological process of spontaneous preterm labor ${ }^{15-42}$. Pathological inflammation can result from the activation of innate immunity ${ }^{43-55}$ by microorganisms ${ }^{29,56-59}$ or endogenous signals derived from necrosis or cellular stress ${ }^{48,51,52,60-65}$, termed damage-associated molecular patterns (DAMPs) ${ }^{66}$ or alarmins ${ }^{67}$. Moreover, it has been demonstrated that activation of the adaptive immune system can also lead to pathological inflammation ${ }^{68}$. Hence, characterization of innate and 
adaptive immune cells and their mediators may provide an understanding into the mechanisms that lead to spontaneous preterm labor.

Recently, a new family of immune cells which belongs to the lymphoid lineage without expressing antigen-specific receptors was described and termed innate lymphoid cells (ILCs) ${ }^{69,70}$. Such cells are defined by three main features: 1 ) the absence of recombination activating gene (RAG)-dependent rearranged antigen receptors; 2) a lack of myeloid cell and dendritic cell phenotypical markers; and 3) their lymphoid morphology 69,70 . Despite lacking antigen recognition capabilities, ILCs exhibit a functional diversity which resembles that of T cells ${ }^{71}$. Two prototypical members of the ILC family have been previously described: the natural killer (NK) cells ${ }^{72}$ and lymphoid tissue-inducer (LTi) cells ${ }^{73}$. These two cell types, while distinct, are related through shared requirement of the common cytokine receptor $\gamma$-chain (IL-2R $\gamma$ ) and the transcriptional repressor inhibitor of DNA binding 2 (ID2) for development ${ }^{70,74}$.

Distinct ILC subsets have since been described which rely on signaling through the IL-7 receptor subunit a (IL-7Ra or CD127) in addition to the abovementioned markers ${ }^{70}$. These new members of the ILC family were classified based on their functional similarities to Tcell subsets ${ }^{70}$. Group 1 ILCs (ILC1) are based on expression of the transcription factor T-bet and include NK cells as well as other IFN $\gamma$-producing Th1-like ILCs ${ }^{75}$. Group 2 ILCs (ILC2) are characterized by Th2-like expression of the cytokines IL-5 and IL-13 and are dependent on the transcription factors GATA-binding protein 3 (GATA3) and retinoic acid receptor-related orphan receptor-a (RORa) for development ${ }^{76,77}$. Finally, group 3 ILCs (ILC3) includes cells which produce Th17-like cytokines including IL-17A and IL-22 and depend on expression of ROR $\gamma^{78}$. Yet, there is plasticity among ILC subsets, which makes their characterization and identification challenging 79,80 .

ILC subsets have been identified in the human decidua during early pregnancy ${ }^{81-86}$; however, whether such cells are present at the human maternal-fetal interface (decidua basalis and decidua parietalis ${ }^{87}$ ) during preterm and term gestations and are implicated in the pathological process of preterm labor is unknown.

The aims of this study were: 1) to determine whether ILCs are present in the decidua of women at preterm and term gestations; 2) to investigate whether the proportions of ILC subsets in the decidua are altered in women who underwent spontaneous preterm labor; and 3 ) to characterize the cytokine signature of decidual ILCs in the pathological process of preterm labor.

\section{Materials and Methods}

\section{Human subjects, clinical specimens, and definitions}

Human placental basal plate and chorioamniotic membrane samples were collected within 30 min after delivery at the Detroit Medical Center, Wayne State University, and the Perinatology Research Branch, an intramural program of the Eunice Kennedy Shriver National Institute of Child Health and Human Development, National Institutes of Health, US Department of Health and Human Services (NICHD/NIH/DHHS), Detroit, MI, USA. 
The collection and utilization of biological materials for research purposes was approved by the Institutional Review Boards of these institutions. All participating women provided written informed consent. The study groups included women who delivered at term with (TIL) or without (TNL) labor and women who delivered preterm with (PTL) or without (PTNL) labor. Two separate sets of samples were utilized in this study: an exploratory and a confirmatory set of samples. The demographic and clinical characteristics of the study populations are shown in Tables 1 and 2. Preterm birth was defined as delivery before 37 weeks of gestation. Labor was defined by the presence of regular uterine contractions at a frequency of at least two contractions every 10 minutes with cervical changes resulting in delivery. For each case, several tissue sections of the chorioamniotic membranes, umbilical cord, and placental disc were evaluated by pathologists who had been blinded to the clinical outcome, according to published criteria ${ }^{88}$. Patients with neonates having congenital or chromosomal abnormalities were excluded.

\section{Decidual leukocyte isolation}

Decidual leukocytes were isolated from the decidual tissue of each study group as previously described ${ }^{87}$. Briefly, the decidua basalis was collected from the basal plate of the placenta and the decidua parietalis was separated from the chorioamniotic membranes. The decidual tissues were homogenized using a gentleMACS Dissociator (Miltenyi Biotec, San Diego, CA, USA) in StemPro Accutase Cell Dissociation Reagent (Life Technologies, Grand Island, NY, USA). Homogenized tissues were incubated in Accutase for $45 \mathrm{~min}$ at $37^{\circ} \mathrm{C}$ with gentle agitation. After incubation, tissues were washed in $1 \times$ phosphate-buffered saline

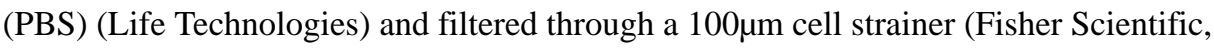
Durham, NC, USA). The resulting cell suspensions were centrifuged at $300 \times \mathrm{g}$ for $10 \mathrm{~min}$ at $4{ }^{\circ} \mathrm{C}$. The decidual mononuclear cells were then separated using a density gradient (FicollPaque Plus; GE Healthcare Biosciences, Uppsala, Sweden) following the manufacturer's instructions. The cells collected from the mononuclear layer of the density gradient were washed with $1 \times$ PBS and immediately used for immunophenotyping.

\section{Immunophenotyping of decidual innate lymphoid cells}

Mononuclear cell suspensions from decidual tissues were stained with the BD Horizon Fixable Viability Stain 510 dye (BD Biosciences) prior to immunophenotyping. Mononuclear cell suspensions were then washed with FACS staining buffer (CAT\#554656; BD Biosciences) and incubated with 20 $\mu$ l of human FcR Blocking Reagent (CAT\#130-059-901; Miltenyi Biotec) in 80 $\mu$ of FACS staining buffer (BD Biosciences) for $10 \mathrm{~min}$ at $4^{\circ} \mathrm{C}$. The cells were incubated with extracellular fluorochrome-conjugated antihuman monoclonal antibodies for $30 \mathrm{~min}$ at $4^{\circ} \mathrm{C}$ in the dark (Supplementary Table 1). After extracellular staining, the cells were fixed and permeabilized using the Foxp3/Transcription Factor Staining Buffer Set (eBioscience, San Diego, CA, USA) prior to staining with intracellular and intranuclear antibodies (Supplementary Table 1). Stained cells were washed and re-suspended in $0.5 \mathrm{~mL}$ of FACS staining buffer and acquired using an LSRFortessa flow cytometer and FACSDiva 6.0 software (BD Biosciences). Data was analyzed using FlowJo software version 10 (TreeStar, Ashland, OR, USA). 


\section{Statistics}

Statistical analyses were performed using SPSS v.19.0 software (SPSS Inc., IBM

Corporation, Armonk, NY). The Mann-Whitney U-test was used for comparisons between study groups or different samples, and the Wilcoxon signed rank paired test was used for comparisons of different subpopulations from the same samples. A p-value $\leq 0.05$ was considered statistically significant.

\section{Results}

The proportion of ILCs is increased in the decidua parietalis of women with spontaneous preterm labor

We first performed an exploratory study to determine the proportions and phenotypes of decidual ILCs in women with spontaneous term or preterm labor and non-labor gestational age-matched controls (Table 1). The gating strategy used to identify ILCs in the decidua parietalis and decidua basalis is shown in Figure 1A. ILCs were identified as CD15-CD14-CD3-CD19-CD56-CD11b-CD127+ cells within the viability gate (Figure 1A). A higher proportion of total ILCs was observed in the decidua parietalis from women who underwent spontaneous preterm labor when compared to patients who delivered preterm without labor (Figure 1B). However, no significant differences were observed in ILCs in the decidua parietalis between women who underwent spontaneous labor at term compared to those who delivered at term in the absence of labor (Figure 1B). No significant differences were observed in the proportion of total ILCs in the decidua parietalis between women who underwent spontaneous preterm labor and those with labor at term (Figure 1B). There were no differences in the proportion of total ILCs in the decidua basalis among the study groups; yet, ILCs tended to be more abundant in the decidua basalis of women with preterm labor than in those who delivered preterm in the absence of labor (Figure 1C). These results show that ILCs are present at the human maternal-fetal interface during preterm and term gestations and an increase in these cells is associated with spontaneous preterm labor.

\section{ILC1s are a minor subset of decidual ILCs during preterm and term gestations}

We continued our exploratory study by characterizing the populations of ILC1s, ILC2s, and ILC3s in the decidua parietalis and decidua basalis (Table 1). ILC1s were distinguished by the expression of the ILC1-associated transcription factor T-bet (Figure 2A). A very small proportion of ILC1s were identified in both the decidua parietalis (median $<2 \%$ ) and basalis (median $<3 \%$ ) (Figure 2B-C). No significant differences in the proportion of decidual ILC1s were found among study groups (Figure 2B-C). These data indicate that ILC1s may not have a significant role in the decidua during preterm and term gestations. Due to the small proportion of ILC1s detected in the decidua, we did not pursue further examination of this population.

\section{ILC2s are the most abundant ILC subset in the decidua during preterm and term gestations}

Our exploratory study revealed that ILC2s were the most abundant ILC subset in the human decidua (data not shown); therefore, we performed a subsequent confirmatory study using a 
different and larger set of samples (Table 2). Decidual ILC2s were determined by the expression of GATA3 on CD127+ ILCs (Figure 3A). In this second cohort, the ILC2 subset was also the most abundant population of ILCs in both the decidua parietalis and decidua basalis (Figure 3B-C). The proportion of ILC2s was higher in the decidua parietalis (median $60-80 \%$ ) than in the decidua basalis (median 35-60\%) of women from each study group (Figure 3B-C). No differences were observed among the proportions of ILC2s in the decidua parietalis of women from each study group; yet, ILC2s tended to be more abundant in preterm than in term gestations (Figure 3B). However, a higher proportion of ILC2s was found in the decidua basalis of women who underwent spontaneous preterm labor compared to non-labor controls (Figure 3C). There were no differences in the proportion of ILC2s in the decidua basalis of women who underwent spontaneous labor at term compared to those who delivered at term in the absence of labor or those who underwent spontaneous preterm labor (Figure 3C). These data show that ILC2s are the dominant ILC population in the decidua parietalis and basalis and that an increase in these cells in the decidua basalis is associated with spontaneous preterm labor.

\section{The proportion of ILC3s is increased in the decidua parietalis of women who underwent spontaneous preterm labor}

Next, we evaluated the presence of ILC3s in the decidual tissues (Table 2). The gating strategy used to determine the proportion of decidual ILC3s by the expression of ROR $\gamma \mathrm{t}$ is shown in Figure 4A. The proportion of ILC3s was significantly increased in the decidua parietalis of women who underwent spontaneous preterm labor compared to that of women who delivered preterm in the absence of labor or those who delivered at term (Figure 4B). The proportion of ILC3s in the decidua basalis did not seem to vary among study groups (Figure 4C). These findings indicate that an increase in ILC3s in the decidua parietalis is associated with spontaneous preterm labor.

\section{Decidual ILC3s express high levels of IL-22, IL17A, IL-13, and IFN $\gamma$ in women with spontaneous preterm labor}

In order to further characterize decidual ILC2s and ILC3s from women with spontaneous preterm labor, we evaluated the expression of cytokines associated with the three ILC subsets (Figure 5A). The mean fluorescence intensity (MFI) of IL-22 (Figure 5B\&C), IL-13 (Figure 5F\&G), and IFN $\gamma$ (Figure 5H\&I) was higher on ILC3s from the decidua parietalis and basalis compared to that of ILC2s. The MFI of IL-17A was solely increased on ILC3s in the decidua parietalis compared to that of ILC2s (Figure 5D). No differences were observed in the expression of IL-5 between ILC2s and ILC3s (data not shown). Together, these data show that decidual ILC3s expressed higher levels of IL-22, IL-17A, IL-13, and IFN $\gamma$ than ILC2s during the pathological process of preterm labor.

\section{Discussion}

\section{Principle findings of the study}

1) The proportion of total CD127+ ILCs was increased in the decidua parietalis of women who underwent spontaneous preterm labor; 2) ILC1s were a minor subset of decidual ILCs during preterm and term gestations; 3) ILC2s were the most abundant ILC subset in the 
decidua during preterm and term gestations; 4) the proportion of ILC2s was increased in the decidua basalis of women who underwent spontaneous preterm labor; 5) the proportion of ILC3s was increased in the decidua parietalis of women who underwent spontaneous preterm labor; 6) ILC3s had higher expression of IL-22, IL-17A, IL-13, and IFN $\gamma$ compared to ILC2s in the decidua of women who underwent spontaneous preterm labor; and 7) decidual ILC2s and ILC3s had similar expression of IL-5 in the decidua of women who underwent spontaneous preterm labor. Collectively, these findings show that, although ILC2s are the most abundant ILC subset at the human maternal-fetal interface during preterm and term gestations, an increase in ILC2s and ILC $3 \mathrm{~s}$ in the decidua basalis and parietalis is observed during the pathological process of preterm labor.

\section{ILCs at the human maternal-fetal interface during preterm and term gestations}

ILCs have been described in mucosal tissues such as the lung, where they contribute to asthma and allergy-related processes ${ }^{89-91}$, and the gastrointestinal tract, where they provide defense against parasitic and microbial infections ${ }^{92-95}$. The discovery of enriched ILCs in mucosal tissues has led to the implication of these cells in chronic intestinal inflammatory disorders such as Crohn's disease ${ }^{96}$. The association between ILCs and inflammatory diseases has led to the search for these cells at other sites of mucosal immunity, such as the reproductive tissues ${ }^{81}$. The three conventional ILC subsets have been described in the murine uterus during early- and mid-gestation, although there is controversy as to which ILC subset is dominant during this period ${ }^{75,78,81,82}$. Indeed, ILC subsets have also been identified in the non-pregnant state in mice ${ }^{97}$ and humans ${ }^{82}$. During early pregnancy, ILC1s and ILC3s are present at the human maternal-fetal interface, where such lymphoid cells crosstalk with neutrophils in order to modulate their migration and function ${ }^{81,85}$. In the study herein, we extended these observations by demonstrating that ILCs are present at the human maternal-fetal interface during term and preterm gestations (i.e. third trimester). Together, these results indicate that ILCs are present at the human maternal-fetal interface; yet, their subsets are dynamically changing throughout gestation and with the onset of preterm labor.

\section{A role for ILC2s at the human maternal-fetal interface during the third trimester and in preterm labor}

ILC2s are a distinct subset of ILCs which bear a functional resemblance to Th2 cells and were first described in a mouse model of helminth parasitic infection as novel producers of the Th2-like cytokines IL-4, IL-5, and IL-13 ${ }^{92}$. ILC2s have been identified in the mesenteric lymph nodes, spleen, liver, intestines, and airways ${ }^{98}$. More recently, ILC2s were abundantly found in the murine uterus during early pregnancy ${ }^{97}$, where their presence may be regulated by female sex hormones (e.g. estrogen) ${ }^{99}$. Herein, we show that ILC2s are the most abundant ILC subset at the human maternal-fetal interface (decidua basalis and decidua parietalis). Tissue ILC2s display homeostatic functions through the secretion of tissue repair factors such as amphiregulin and IL-13 ${ }^{100-102}$, which properties resemble those exhibited by M2 decidual macrophages in term and preterm gestations ${ }^{50}$. Therefore, we suggest that ILC2s, as well as M2 macrophages ${ }^{103}$, display homeostatic roles at the human maternal-fetal interface during the third trimester. 
Besides displaying homeostatic functions, ILC2s also exhibit pro-inflammatory functions.

For example, ILC2s can contribute to the pathogenesis of ulcerative colitis, a chronic disease which is characterized by the elevated concentrations of Th2 cytokines such as IL-4, IL-5, and IL-13 ${ }^{104,105}$. Herein, we found that the proportion of ILC2s was increased in the decidua basalis of women who underwent spontaneous preterm labor. Interestingly, preterm labor is associated with chronic inflammatory lesions of the placenta ${ }^{106}$ (e.g. chronic deciduitis, infiltration of lymphocytes or plasma cells in the basal plate of the placenta ${ }^{107}$ ), which provides evidence that preterm labor can also be a chronic inflammatory disease. These data indicate that ILC2s may participate in the chronic inflammatory microenvironment that accompanies the pathological process of preterm labor in the decidua basalis.

\section{A role for ILC3s at the human maternal-fetal interface during preterm labor}

ILC3s were first described in the small intestine as unique innate cells that express the transcription factor ROR $\gamma \mathrm{t}$ and the cytokine IL-22108, 109, and were later shown to produce IL-17A $\mathrm{A}^{110,111}$. ILC3s have been studied primarily in the context of inflammatory bowel disorders and other gastrointestinal diseases due to their presence in the gut mucosa and interactions with commensal bacteria ${ }^{93,112}$. Moreover, ROR $\gamma \mathrm{t}+$ ILC3s can express MHC class II and process and present microbial antigens to gut $\mathrm{T}$ cells ${ }^{113}$. This presentation of microbial peptides in the gut results in diminished commensal bacteria-specific $\mathrm{T}$ cell responses $^{113}$. In addition, IL-23-responsive ILC3s producing IL-17A and IL-22 have been implicated in the development of colitis in mouse models and in human studies ${ }^{96}$. In the current study, ILC3s were enriched in the decidua parietalis (decidua attached to the chorioamniotic membranes ${ }^{87}$ ) of women who underwent spontaneous preterm labor. Such ILCs expressed high levels of IL-22 and IL17A, suggesting that this subset is implicated in the localized inflammatory milieu that accompanies the pathological process of preterm labor.

Herein, we found that decidual ILCs expressed high levels of IL-13 (a cytokine mainly produced by ILC2 $\mathrm{s}^{91,92}$ ) during the process of preterm labor. In line with this observation, previous studies have demonstrated that IL-13 is expressed by the placental ${ }^{114}$ and decidual tissues ${ }^{115,116}$. IL-13 promotes the activation and migration of dendritic cells into the draining lymph nodes, leading to the differentiation of Th2 cells ${ }^{117}$. This cytokine is also important for tissue repair responses, reduction of ILC3-mediated inflammation, and defense against parasitic infections ${ }^{101,118}$. Together, these results allow us to propose that decidual ILC3s express high levels of the anti-inflammatory cytokine IL-13 in order to regulate the inflammatory responses exhibited by such cells.

Interestingly, ILC3s are also capable of expressing IFN $\gamma$ when exposed to IL-12, IL-18, and/or IL-1 $\beta$ by upregulating T-bet, suggesting that a small proportion of ILC1s are derived from ILC $3 \mathrm{~s}^{79}$. In the current study, we found that decidual ILC3s expressed high levels of IFN $\gamma$, besides expressing ILC3 cytokines. Collectively, these results indicate that decidual ILC3s express ILC1 and ILC2 cytokines, supporting the concept that immune cells at the maternal-fetal interface display unique phenotypical characteristics ${ }^{119}$. 


\section{Summary}

In the current study, we provide evidence that ILCs are present at the human maternal-fetal interface; yet, their subsets are dynamically changing throughout late gestation and with the onset of preterm labor. First, we found that ILC2s are the most abundant ILC subset at the human maternal-fetal interface and that their proportions in the decidua basalis (decidua attached to the placenta) increased in women who underwent spontaneous preterm labor. Next, we showed that ILC3s are enriched in the decidua parietalis (decidua attached to the chorioamniotic membranes) in women who underwent spontaneous preterm labor. Lastly, we demonstrated that ILC3s expressed high levels of IL-22, IL-17A, IL-13, and IFN $\gamma$ at the human maternal-fetal interface during preterm labor. Collectively, these data provide the first evidence demonstrating a role for ILCs at the human maternal-fetal interface during the pathological process of preterm labor.

\section{Supplementary Material}

Refer to Web version on PubMed Central for supplementary material.

\section{Acknowledgments}

This research was supported, in part, by the Perinatology Research Branch (PRB), Division of Intramural Research, Eunice Kennedy Shriver National Institute of Child Health and Human Development, National Institutes of Health, U.S. Department of Health and Human Services (NICHD/NIH/DHHS), and, in part, with federal funds from the NICHD/NIH/DHHS under Contract No.HHSN275201300006C. This research was also supported by the Wayne State University Perinatal Initiative in Maternal, Perinatal and Child Health. We thank the physicians and nurses from the Center for Advanced Obstetrical Care and Research and the Intrapartum Unit, as well as the research assistants from the PRB Clinical Laboratory, for their help in collecting samples.

\section{References}

1. Romero R, Mazor M, Munoz H, Gomez R, Galasso M, Sherer DM. The preterm labor syndrome. Ann N Y Acad Sci. 1994; 734:414-429. [PubMed: 7978942]

2. Romero R, Espinoza J, Kusanovic JP, Gotsch F, Hassan S, Erez O, Chaiworapongsa T, Mazor M. The preterm parturition syndrome. BJOG. 2006; 113(Suppl 3):17-42.

3. Gotsch F, Gotsch F, Romero R, Erez O, Vaisbuch E, Kusanovic JP, Mazaki-Tovi S, Kim SK, Hassan $\mathrm{S}$, Yeo L. The preterm parturition syndrome and its implications for understanding the biology, risk assessment, diagnosis, treatment and prevention of preterm birth. J Matern Fetal Neonatal Med. 2009; 22(Suppl 2):5-23. [PubMed: 19951079]

4. Muglia LJ, Katz M. The enigma of spontaneous preterm birth. N Engl J Med. 2010; 362:529-535. [PubMed: 20147718]

5. Blencowe H, Cousens S, Oestergaard MZ, Chou D, Moller AB, Narwal R, Adler A, Vera Garcia C, Rohde S, Say L, Lawn JE. National, regional, and worldwide estimates of preterm birth rates in the year 2010 with time trends since 1990 for selected countries: a systematic analysis and implications. Lancet. 2012; 379:2162-2172. [PubMed: 22682464]

6. Hamilton BE, Hoyert DL, Martin JA, Strobino DM, Guyer B. Annual summary of vital statistics: 2010-2011. Pediatrics. 2013; 131:548-558. [PubMed: 23400611]

7. Monier I, Ancel PY, Ego A, Jarreau PH, Lebeaux C, Kaminski M, Goffinet F, Zeitlin J, Group ES. Fetal and neonatal outcomes of preterm infants born before 32 weeks of gestation according to antenatal vs postnatal assessments of restricted growth. Am J Obstet Gynecol. 2017; 216:516 e511516 e510. [PubMed: 28188770]

8. Travers CP, Carlo WA, McDonald SA, Das A, Bell EF, Ambalavanan N, Jobe AH, Goldberg RN, D'Angio CT, Stoll BJ, Shankaran S, Laptook AR, Schmidt B, Walsh MC, Sanchez PJ, Ball MB, Hale EC, Newman NS, Higgins RD. Eunice Kennedy Shriver National Institute of Child H, Human 
Development Neonatal Research N. Mortality and Pulmonary Outcomes of Extremely Preterm Infants Exposed to Antenatal Corticosteroids. Am J Obstet Gynecol. 2017

9. Martin JA, Hamilton BE, Osterman MJ, Curtin SC, Matthews TJ. Births: final data for 2013. Natl Vital Stat Rep. 2015; 64:1-65.

10. Lubow JM, How HY, Habli M, Maxwell R, Sibai BM. Indications for delivery and short-term neonatal outcomes in late preterm as compared with term births. Am J Obstet Gynecol. 2009; 200:e30-33. [PubMed: 19136092]

11. Mwaniki MK, Atieno M, Lawn JE, Newton CR. Long-term neurodevelopmental outcomes after intrauterine and neonatal insults: a systematic review. Lancet. 2012; 379:445-452. [PubMed: 22244654]

12. Manuck TA, Rice MM, Bailit JL, Grobman WA, Reddy UM, Wapner RJ, Thorp JM, Caritis SN, Prasad M, Tita AT, Saade GR, Sorokin Y, Rouse DJ, Blackwell SC, Tolosa JE. Eunice Kennedy Shriver National Institute of Child H, Human Development Maternal-Fetal Medicine Units N. Preterm neonatal morbidity and mortality by gestational age: a contemporary cohort. Am J Obstet Gynecol. 2016; 215:103 e101-103 e114. [PubMed: 26772790]

13. Chevallier M, Debillon T, Pierrat V, Delorme P, Kayem G, Durox M, Goffinet F, Marret S, Ancel PY. Neurodevelopment EWG: Leading causes of preterm delivery as risk factors for intraventricular hemorrhage in very preterm infants: results of the EPIPAGE 2 cohort study. Am J Obstet Gynecol. 2017; 216:518 e511-518 e512. [PubMed: 28104401]

14. Goldenberg RL, Culhane JF, Iams JD, Romero R. Epidemiology and causes of preterm birth. Lancet. 2008; 371:75-84. [PubMed: 18177778]

15. Romero R, Dey SK, Fisher SJ. Preterm labor: one syndrome, many causes. Science. 2014; 345:760-765. [PubMed: 25124429]

16. Romero R, Sirtori M, Oyarzun E, Avila C, Mazor M, Callahan R, Sabo V, Athanassiadis AP, Hobbins JC. Infection and labor. V. Prevalence, microbiology, and clinical significance of intraamniotic infection in women with preterm labor and intact membranes. Am J Obstet Gynecol. 1989; 161:817-824. [PubMed: 2675611]

17. Romero R, Avila C, Santhanam U, Sehgal PB. Amniotic fluid interleukin 6 in preterm labor. Association with infection. J Clin Invest. 1990; 85:1392-1400. [PubMed: 2332497]

18. Romero R, Quintero R, Nores J, Avila C, Mazor M, Hanaoka S, Hagay Z, Merchant L, Hobbins JC. Amniotic fluid white blood cell count: a rapid and simple test to diagnose microbial invasion of the amniotic cavity and predict preterm delivery. Am J Obstet Gynecol. 1991; 165:821-830. [PubMed: 1951538]

19. Andrews WW, Hauth JC, Goldenberg RL, Gomez R, Romero R, Cassell GH. Amniotic fluid interleukin-6: correlation with upper genital tract microbial colonization and gestational age in women delivered after spontaneous labor versus indicated delivery. Am J Obstet Gynecol. 1995; 173:606-612. [PubMed: 7645642]

20. Romero R, Gomez R, Chaiworapongsa T, Conoscenti G, Kim JC, Kim YM. The role of infection in preterm labour and delivery. Paediatr Perinat Epidemiol. 2001; 15(Suppl 2):41-56. [PubMed: 11520399]

21. Yoon BH, Chang JW, Romero R. Isolation of Ureaplasma urealyticum from the amniotic cavity and adverse outcome in preterm labor. Obstet Gynecol. 1998; 92:77-82. [PubMed: 9649098]

22. Yoon BH, Jun JK, Park KH, Syn HC, Gomez R, Romero R. Serum C-reactive protein, white blood cell count, and amniotic fluid white blood cell count in women with preterm premature rupture of membranes. Obstet Gynecol. 1996; 88:1034-1040. [PubMed: 8942849]

23. Yoon BH, Romero R, Kim M, Kim EC, Kim T, Park JS, Jun JK. Clinical implications of detection of Ureaplasma urealyticum in the amniotic cavity with the polymerase chain reaction. Am J Obstet Gynecol. 2000; 183:1130-1137. [PubMed: 11084554]

24. Jacobsson B, Mattsby-Baltzer I, Andersch B, Bokstrom H, Holst RM, Wennerholm UB, Hagberg $\mathrm{H}$. Microbial invasion and cytokine response in amniotic fluid in a Swedish population of women in preterm labor. Acta Obstet Gynecol Scand. 2003; 82:120-128. [PubMed: 12648172]

25. Shim SS, Romero R, Hong JS, Park CW, Jun JK, Kim BI, Yoon BH. Clinical significance of intraamniotic inflammation in patients with preterm premature rupture of membranes. Am J Obstet Gynecol. 2004; 191:1339-1345. [PubMed: 15507963] 
26. Yoon BH, Romero R, Moon JB, Shim SS, Kim M, Kim G, Jun JK. Clinical significance of intraamniotic inflammation in patients with preterm labor and intact membranes. Am J Obstet Gynecol. 2001; 185:1130-1136. [PubMed: 11717646]

27. Cobo T, Palacio M, Martinez-Terron M, Navarro-Sastre A, Bosch J, Filella X, Gratacos E. Clinical and inflammatory markers in amniotic fluid as predictors of adverse outcomes in preterm premature rupture of membranes. Am J Obstet Gynecol. 2011; 205:126, e121-128. [PubMed: 21621184]

28. Lee SE, Romero R, Jung H, Park CW, Park JS, Yoon BH. The intensity of the fetal inflammatory response in intraamniotic inflammation with and without microbial invasion of the amniotic cavity. Am J Obstet Gynecol. 2007; 197:294, e291-296. [PubMed: 17826426]

29. Romero R, Espinoza J, Goncalves LF, Kusanovic JP, Friel L, Hassan S. The role of inflammation and infection in preterm birth. Semin Reprod Med. 2007; 25:21-39. [PubMed: 17205421]

30. Romero R, Miranda J, Chaiworapongsa T, Chaemsaithong P, Gotsch F, Dong Z, Ahmed AI, Yoon BH, Hassan SS, Kim CJ, Korzeniewski SJ, Yeo L. A novel molecular microbiologic technique for the rapid diagnosis of microbial invasion of the amniotic cavity and intra-amniotic infection in preterm labor with intact membranes. Am J Reprod Immunol. 2014; 71:330-358. [PubMed: 24417618]

31. Romero R, Miranda J, Chaiworapongsa T, Chaemsaithong P, Gotsch F, Dong Z, Ahmed AI, Yoon BH, Hassan SS, Kim CJ, Korzeniewski SJ, Yeo L, Kim YM. Sterile intra-amniotic inflammation in asymptomatic patients with a sonographic short cervix: prevalence and clinical significance. J Matern Fetal Neonatal Med. 2014:1-17.

32. Romero R, Miranda J, Chaiworapongsa T, Korzeniewski SJ, Chaemsaithong P, Gotsch F, Dong Z, Ahmed AI, Yoon BH, Hassan SS, Kim CJ, Yeo L. Prevalence and clinical significance of sterile intra-amniotic inflammation in patients with preterm labor and intact membranes. Am J Reprod Immunol. 2014; 72:458-474. [PubMed: 25078709]

33. Combs CA, Gravett M, Garite TJ, Hickok DE, Lapidus J, Porreco R, Rael J, Grove T, Morgan TK, Clewell W, Miller H, Luthy D, Pereira L, Nageotte M, Robilio PA, Fortunato S, Simhan H, Baxter JK, Amon E, Franco A, Trofatter K, Heyborne K. ProteoGenix/Obstetrix Collaborative Research N. Amniotic fluid infection, inflammation, and colonization in preterm labor with intact membranes. Am J Obstet Gynecol. 2014; 210:125 e121-125 e115. [PubMed: 24274987]

34. Romero R, Miranda J, Chaemsaithong P, Chaiworapongsa T, Kusanovic JP, Dong Z, Ahmed AI, Shaman M, Lannaman K, Yoon BH, Hassan SS, Kim CJ, Korzeniewski SJ, Yeo L, Kim YM. Sterile and microbial-associated intra-amniotic inflammation in preterm prelabor rupture of membranes. J Matern Fetal Neonatal Med. 2015; 28:1394-1409. [PubMed: 25190175]

35. Gervasi MT, Chaiworapongsa T, Naccasha N, Blackwell S, Yoon BH, Maymon E, Romero R. Phenotypic and metabolic characteristics of maternal monocytes and granulocytes in preterm labor with intact membranes. Am J Obstet Gynecol. 2001; 185:1124-1129. [PubMed: 11717645]

36. Gervasi MT, Chaiworapongsa T, Naccasha N, Pacora P, Berman S, Maymon E, Kim JC, Kim YM, Yoshimatsu J, Espinoza J, Romero R. Maternal intravascular inflammation in preterm premature rupture of membranes. J Matern Fetal Neonatal Med. 2002; 11:171-175. [PubMed: 12380672]

37. Kacerovsky M, Musilova I, Andrys C, Hornychova H, Pliskova L, Kostal M, Jacobsson B. Prelabor rupture of membranes between 34 and 37 weeks: the intraamniotic inflammatory response and neonatal outcomes. Am J Obstet Gynecol. 2014; 210:325 e321-325 e310. [PubMed: 24184182]

38. Yoneda N, Yoneda S, Niimi H, Ueno T, Hayashi S, Ito M, Shiozaki A, Urushiyama D, Hata K, Suda W, Hattori M, Kigawa M, Kitajima I, Saito S. Polymicrobial Amniotic Fluid Infection with Mycoplasma/Ureaplasma and Other Bacteria Induces Severe Intra-Amniotic Inflammation Associated with Poor Perinatal Prognosis in Preterm Labor. Am J Reprod Immunol. 2016; 75:112125. [PubMed: 26668114]

39. Oh KJ, Kim SM, Hong JS, Maymon E, Erez O, Panaitescu B, Gomez-Lopez N, Romero R, Yoon $\mathrm{BH}$. Twenty-four percent of patients with clinical chorioamnionitis in preterm gestations have no evidence of either culture-proven intraamniotic infection or intraamniotic inflammation. Am J Obstet Gynecol. 2017; 216:604 e601-604 e611. [PubMed: 28257964]

40. Romero R, Chaemsaithong P, Chaiyasit N, Docheva N, Dong Z, Kim CJ, Kim YM, Kim JS, Qureshi F, Jacques SM, Yoon BH, Chaiworapongsa T, Yeo L, Hassan SS, Erez O, Korzeniewski 
SJ. CXCL10 and IL-6: Markers of two different forms of intra-amniotic inflammation in preterm labor. Am J Reprod Immunol. 2017; 78

41. Gomez-Lopez N, Romero R, Xu Y, Leng Y, Garcia-Flores V, Miller D, Jacques SM, Hassan SS, Faro J, Alsamsam A, Alhousseini A, Gomez-Roberts H, Panaitescu B, Yeo L, Maymon E. Are amniotic fluid neutrophils in women with intraamniotic infection and/or inflammation of fetal or maternal origin? Am J Obstet Gynecol. 2017; 217:693 e691-693 e616. [PubMed: 28964823]

42. Tarca AL, Fitzgerald W, Chaemsaithong P, Xu Z, Hassan SS, Grivel JC, Gomez-Lopez N, Panaitescu B, Pacora P, Maymon E, Erez O, Margolis L, Romero R. The cytokine network in women with an asymptomatic short cervix and the risk of preterm delivery. Am J Reprod Immunol. 2017; 78

43. Cardenas I, Means RE, Aldo P, Koga K, Lang SM, Booth CJ, Manzur A, Oyarzun E, Romero R, Mor G. Viral infection of the placenta leads to fetal inflammation and sensitization to bacterial products predisposing to preterm labor. J Immunol. 2010; 185:1248-1257. [PubMed: 20554966]

44. Cardenas I, Mulla MJ, Myrtolli K, Sfakianaki AK, Norwitz ER, Tadesse S, Guller S, Abrahams VM. Nod1 activation by bacterial iE-DAP induces maternal-fetal inflammation and preterm labor. J Immunol. 2011; 187:980-986. [PubMed: 21677137]

45. Jaiswal MK, Agrawal V, Mallers T, Gilman-Sachs A, Hirsch E, Beaman KD. Regulation of apoptosis and innate immune stimuli in inflammation-induced preterm labor. J Immunol. 2013; 191:5702-5713. [PubMed: 24163412]

46. Kim YM, Romero R, Chaiworapongsa T, Kim GJ, Kim MR, Kuivaniemi H, Tromp G, Espinoza J, Bujold E, Abrahams VM, Mor G. Toll-like receptor-2 and -4 in the chorioamniotic membranes in spontaneous labor at term and in preterm parturition that are associated with chorioamnionitis. Am J Obstet Gynecol. 2004; 191:1346-1355. [PubMed: 15507964]

47. Koga K, Cardenas I, Aldo P, Abrahams VM, Peng B, Fill S, Romero R, Mor G. Activation of TLR3 in the trophoblast is associated with preterm delivery. Am J Reprod Immunol. 2009; 61:196-212. [PubMed: 19239422]

48. Romero R, Chaiworapongsa T, Alpay Savasan Z, Xu Y, Hussein Y, Dong Z, Kusanovic JP, Kim CJ, Hassan SS. Damage-associated molecular patterns (DAMPs) in preterm labor with intact membranes and preterm PROM: a study of the alarmin HMGB1. J Matern Fetal Neonatal Med. 2011; 24:1444-1455. [PubMed: 21958433]

49. Vaisbuch E, Romero R, Erez O, Mazaki-Tovi S, Kusanovic JP, Soto E, Dong Z, Chaiworapongsa T, Kim SK, Ogge G, Pacora P, Yeo L, Hassan SS. Activation of the alternative pathway of complement is a feature of pre-term parturition but not of spontaneous labor at term. Am J Reprod Immunol. 2010; 63:318-330. [PubMed: 20163401]

50. Xu Y, Romero R, Miller D, Kadam L, Mial TN, Plazyo O, Garcia-Flores V, Hassan SS, Xu Z, Tarca AL, Drewlo S, Gomez-Lopez N. An M1-like Macrophage Polarization in Decidual Tissue during Spontaneous Preterm Labor That Is Attenuated by Rosiglitazone Treatment. J Immunol. 2016; 196:2476-2491. [PubMed: 26889045]

51. St Louis D, Romero R, Plazyo O, Arenas-Hernandez M, Panaitescu B, Xu Y, Milovic T, Xu Z, Bhatti G, Mi QS, Drewlo S, Tarca AL, Hassan SS, Gomez-Lopez N. Invariant NKT Cell Activation Induces Late Preterm Birth That Is Attenuated by Rosiglitazone. J Immunol. 2016; 196:1044-1059. [PubMed: 26740111]

52. Gomez-Lopez N, Romero R, Arenas-Hernandez M, Schwenkel G, St Louis D, Hassan SS, Mial $\mathrm{TN}$. In vivo activation of invariant natural killer T cells induces systemic and local alterations in Tcell subsets prior to preterm birth. Clin Exp Immunol. 2017; 189:211-225. [PubMed: 28369855]

53. Anders AP, Gaddy JA, Doster RS, Aronoff DM. Current concepts in maternal-fetal immunology: Recognition and response to microbial pathogens by decidual stromal cells. Am J Reprod Immunol. 2017; 77

54. Gomez-Lopez N, Romero R, Xu Y, Plazyo O, Unkel R, Leng Y, Than NG, Chaiworapongsa T, Panaitescu B, Dong Z, Tarca AL, Abrahams VM, Yeo L, Hassan SS. A Role for the Inflammasome in Spontaneous Preterm Labor With Acute Histologic Chorioamnionitis. Reprod Sci. 2017; 24:1382-1401. [PubMed: 28122480]

55. Negishi Y, Shima Y, Takeshita T, Takahashi H. Distribution of invariant natural killer T cells and dendritic cells in late pre-term birth without acute chorioamnionitis. Am J Reprod Immunol. 2017; 77 
56. Thaxton JE, Nevers TA, Sharma S. TLR-mediated preterm birth in response to pathogenic agents. Infect Dis Obstet Gynecol. 2010; 2010

57. Racicot K, Kwon JY, Aldo P, Abrahams V, El-Guindy A, Romero R, Mor G. Type I Interferon Regulates the Placental Inflammatory Response to Bacteria and is Targeted by Virus: Mechanism of Polymicrobial Infection-Induced Preterm Birth. Am J Reprod Immunol. 2016; 75:451-460. [PubMed: 26892235]

58. Gomez-Lopez N, Romero R, Xu Y, Miller D, Unkel R, Shaman M, Jacques SM, Panaitescu B, Garcia-Flores V, Hassan SS. Neutrophil Extracellular Traps in the Amniotic Cavity of Women with Intra-Amniotic Infection: A New Mechanism of Host Defense. Reprod Sci. 2017; 24:1139_ 1153. [PubMed: 27884950]

59. Gomez-Lopez N, Romero R, Garcia-Flores V, Xu Y, Leng Y, Alhousseini A, Hassan SS, Panaitescu B. Amniotic fluid neutrophils can phagocytize bacteria: A mechanism for microbial killing in the amniotic cavity. Am J Reprod Immunol. 2017; 78

60. Friel LA, Romero R, Edwin S, Nien JK, Gomez R, Chaiworapongsa T, Kusanovic JP, Tolosa JE, Hassan SS, Espinoza J. The calcium binding protein, S100B, is increased in the amniotic fluid of women with intra-amniotic infection/inflammation and preterm labor with intact or ruptured membranes. J Perinat Med. 2007; 35:385-393. [PubMed: 17624933]

61. Chaiworapongsa T, Erez O, Kusanovic JP, Vaisbuch E, Mazaki-Tovi S, Gotsch F, Than NG, Mittal P, Kim YM, Camacho N, Edwin S, Gomez R, Hassan SS, Romero R. Amniotic fluid heat shock protein 70 concentration in histologic chorioamnionitis, term and preterm parturition. J Matern Fetal Neonatal Med. 2008; 21:449-461. [PubMed: 18570125]

62. Romero R, Espinoza J, Hassan S, Gotsch F, Kusanovic JP, Avila C, Erez O, Edwin S, Schmidt AM. Soluble receptor for advanced glycation end products (sRAGE) and endogenous secretory RAGE (esRAGE) in amniotic fluid: modulation by infection and inflammation. J Perinat Med. 2008; 36:388-398. [PubMed: 18593373]

63. Lee SE, Park IS, Romero R, Yoon BH. Amniotic fluid prostaglandin F2 increases even in sterile amniotic fluid and is an independent predictor of impending delivery in preterm premature rupture of membranes. J Matern Fetal Neonatal Med. 2009; 22:880-886. [PubMed: 19544157]

64. Gomez-Lopez N, Romero R, Plazyo O, Panaitescu B, Furcron AE, Miller D, Roumayah T, Flom E, Hassan SS. Intra-Amniotic Administration of HMGB1 Induces Spontaneous Preterm Labor and Birth. Am J Reprod Immunol. 2016; 75:3-7. [PubMed: 26781934]

65. Plazyo O, Romero R, Unkel R, Balancio A, Mial TN, Xu Y, Dong Z, Hassan SS, Gomez-Lopez N. HMGB1 Induces an Inflammatory Response in the Chorioamniotic Membranes That Is Partially Mediated by the Inflammasome. Biol Reprod. 2016; 95:130. [PubMed: 27806943]

66. Lotze MT, Deisseroth A, Rubartelli A. Damage associated molecular pattern molecules. Clin Immunol. 2007; 124:1-4. [PubMed: 17468050]

67. Oppenheim JJ, Yang D. Alarmins: chemotactic activators of immune responses. Curr Opin Immunol. 2005; 17:359-365. [PubMed: 15955682]

68. Gomez-Lopez N, Romero R, Arenas-Hernandez M, Ahn H, Panaitescu B, Vadillo-Ortega F, Sanchez-Torres C, Salisbury KS, Hassan SS. In vivo T-cell activation by a monoclonal alphaCD3epsilon antibody induces preterm labor and birth. Am J Reprod Immunol. 2016; 76:386390. [PubMed: 27658719]

69. Spits H, Cupedo T. Innate lymphoid cells: emerging insights in development, lineage relationships, and function. Annu Rev Immunol. 2012; 30:647-675. [PubMed: 22224763]

70. Spits H, Artis D, Colonna M, Diefenbach A, Di Santo JP, Eberl G, Koyasu S, Locksley RM, McKenzie AN, Mebius RE, Powrie F, Vivier E. Innate lymphoid cells--a proposal for uniform nomenclature. Nat Rev Immunol. 2013; 13:145-149. [PubMed: 23348417]

71. Klose CS, Artis D. Innate lymphoid cells as regulators of immunity, inflammation and tissue homeostasis. Nat Immunol. 2016; 17:765-774. [PubMed: 27328006]

72. Kiessling R, Klein E, Pross H, Wigzell H. "Natural" killer cells in the mouse. II. Cytotoxic cells with specificity for mouse Moloney leukemia cells. Characteristics of the killer cell. Eur J Immunol. 1975; 5:117-121. [PubMed: 1086218] 
73. Mebius RE, Rennert P, Weissman IL. Developing lymph nodes collect CD4+CD3- LTbeta+ cells that can differentiate to APC, NK cells, and follicular cells but not T or B cells. Immunity. 1997; 7:493-504. [PubMed: 9354470]

74. Yokota Y, Mansouri A, Mori S, Sugawara S, Adachi S, Nishikawa S, Gruss P. Development of peripheral lymphoid organs and natural killer cells depends on the helix-loop-helix inhibitor Id2. Nature. 1999; 397:702-706. [PubMed: 10067894]

75. Powell N, Walker AW, Stolarczyk E, Canavan JB, Gokmen MR, Marks E, Jackson I, Hashim A, Curtis MA, Jenner RG, Howard JK, Parkhill J, MacDonald TT, Lord GM. The transcription factor T-bet regulates intestinal inflammation mediated by interleukin-7 receptor+ innate lymphoid cells. Immunity. 2012; 37:674-684. [PubMed: 23063332]

76. Mjosberg J, Bernink J, Golebski K, Karrich JJ, Peters CP, Blom B, te Velde AA, Fokkens WJ, van Drunen CM, Spits H. The transcription factor GATA3 is essential for the function of human type 2 innate lymphoid cells. Immunity. 2012; 37:649-659. [PubMed: 23063330]

77. Wong SH, Walker JA, Jolin HE, Drynan LF, Hams E, Camelo A, Barlow JL, Neill DR, Panova V, Koch U, Radtke F, Hardman CS, Hwang YY, Fallon PG, McKenzie AN. Transcription factor RORalpha is critical for nuocyte development. Nat Immunol. 2012; 13:229-236. [PubMed: 22267218]

78. Eberl G, Marmon S, Sunshine MJ, Rennert PD, Choi Y, Littman DR. An essential function for the nuclear receptor RORgamma(t) in the generation of fetal lymphoid tissue inducer cells. Nat Immunol. 2004; 5:64-73. [PubMed: 14691482]

79. Bernink JH, Peters CP, Munneke M, te Velde AA, Meijer SL, Weijer K, Hreggvidsdottir HS, Heinsbroek SE, Legrand N, Buskens CJ, Bemelman WA, Mjosberg JM, Spits H. Human type 1 innate lymphoid cells accumulate in inflamed mucosal tissues. Nat Immunol. 2013; 14:221-229. [PubMed: 23334791]

80. Klose CS, Kiss EA, Schwierzeck V, Ebert K, Hoyler T, d'Hargues Y, Goppert N, Croxford AL, Waisman A, Tanriver Y, Diefenbach A. A T-bet gradient controls the fate and function of CCR6RORgammat+ innate lymphoid cells. Nature. 2013; 494:261-265. [PubMed: 23334414]

81. Vacca P, Montaldo E, Croxatto D, Loiacono F, Canegallo F, Venturini PL, Moretta L, Mingari MC. Identification of diverse innate lymphoid cells in human decidua. Mucosal Immunol. 2015; 8:254 264. [PubMed: 25052762]

82. Doisne JM, Balmas E, Boulenouar S, Gaynor LM, Kieckbusch J, Gardner L, Hawkes DA, Barbara CF, Sharkey AM, Brady HJ, Brosens JJ, Moffett A, Colucci F. Composition, Development, and Function of Uterine Innate Lymphoid Cells. J Immunol. 2015; 195:3937-3945. [PubMed: 26371244]

83. Zhang J, Dunk C, Croy AB, Lye SJ. To serve and to protect: the role of decidual innate immune cells on human pregnancy. Cell Tissue Res. 2016; 363:249-265. [PubMed: 26572540]

84. Boulenouar S, Doisne JM, Sferruzzi-Perri A, Gaynor LM, Kieckbusch J, Balmas E, Yung HW, Javadzadeh S, Volmer L, Hawkes DA, Phillips K, Brady HJ, Fowden AL, Burton GJ, Moffett A, Colucci F. The Residual Innate Lymphoid Cells in NFIL3-Deficient Mice Support Suboptimal Maternal Adaptations to Pregnancy. Front Immunol. 2016; 7:43. [PubMed: 26925058]

85. Croxatto D, Micheletti A, Montaldo E, Orecchia P, Loiacono F, Canegallo F, Calzetti F, Fulcheri E, Munari E, Zamo A, Venturini PL, Moretta L, Cassatella MA, Mingari MC, Vacca P. Group 3 innate lymphoid cells regulate neutrophil migration and function in human decidua. Mucosal Immunol. 2016; 9:1372-1383. [PubMed: 26906405]

86. Gaynor LM, Colucci F. Uterine Natural Killer Cells: Functional Distinctions and Influence on Pregnancy in Humans and Mice. Front Immunol. 2017; 8:467. [PubMed: 28484462]

87. Xu Y, Plazyo O, Romero R, Hassan SS, Gomez-Lopez N. Isolation of Leukocytes from the Human Maternal-fetal Interface. J Vis Exp. 2015:e52863. [PubMed: 26067211]

88. Kim CJ, Romero R, Chaemsaithong P, Chaiyasit N, Yoon BH, Kim YM. Acute chorioamnionitis and funisitis: definition, pathologic features, and clinical significance. Am J Obstet Gynecol. 2015; 213:S29-52. [PubMed: 26428501]

89. Halim TY, Krauss RH, Sun AC, Takei F. Lung natural helper cells are a critical source of Th2 celltype cytokines in protease allergen-induced airway inflammation. Immunity. 2012; 36:451-463.

[PubMed: 22425247] 
90. Kim HY, Chang YJ, Subramanian S, Lee HH, Albacker LA, Matangkasombut P, Savage PB, McKenzie AN, Smith DE, Rottman JB, DeKruyff RH, Umetsu DT. Innate lymphoid cells responding to IL-33 mediate airway hyperreactivity independently of adaptive immunity. J Allergy Clin Immunol. 2012; 129:216-227. e211-216. [PubMed: 22119406]

91. Klein Wolterink RG, Kleinjan A, van Nimwegen M, Bergen I, de Bruijn M, Levani Y, Hendriks RW. Pulmonary innate lymphoid cells are major producers of IL-5 and IL-13 in murine models of allergic asthma. Eur J Immunol. 2012; 42:1106-1116. [PubMed: 22539286]

92. Fallon PG, Ballantyne SJ, Mangan NE, Barlow JL, Dasvarma A, Hewett DR, McIlgorm A, Jolin HE, McKenzie AN. Identification of an interleukin (IL)-25-dependent cell population that provides IL-4, IL-5, and IL-13 at the onset of helminth expulsion. J Exp Med. 2006; 203:11051116. [PubMed: 16606668]

93. Cella M, Fuchs A, Vermi W, Facchetti F, Otero K, Lennerz JK, Doherty JM, Mills JC, Colonna M. A human natural killer cell subset provides an innate source of IL-22 for mucosal immunity. Nature. 2009; 457:722-725. [PubMed: 18978771]

94. Gladiator A, Wangler N, Trautwein-Weidner K, LeibundGut-Landmann S. Cutting edge: IL-17secreting innate lymphoid cells are essential for host defense against fungal infection. J Immunol. 2013; 190:521-525. [PubMed: 23255360]

95. Klose CSN, Flach M, Mohle L, Rogell L, Hoyler T, Ebert K, Fabiunke C, Pfeifer D, Sexl V, Fonseca-Pereira D, Domingues RG, Veiga-Fernandes H, Arnold SJ, Busslinger M, Dunay IR, Tanriver Y, Diefenbach A. Differentiation of type 1 ILCs from a common progenitor to all helperlike innate lymphoid cell lineages. Cell. 2014; 157:340-356. [PubMed: 24725403]

96. Geremia A, Arancibia-Carcamo CV. Innate Lymphoid Cells in Intestinal Inflammation. Front Immunol. 2017; 8:1296. [PubMed: 29081776]

97. Li M, Gao Y, Yong L, Huang D, Shen J, Liu M, Ren C, Hou X. Molecular signature and functional analysis of uterine ILCs in mouse pregnancy. J Reprod Immunol. 2017; 123:48-57. [PubMed: 28915450]

98. Walker JA, Barlow JL, McKenzie AN. Innate lymphoid cells--how did we miss them? Nat Rev Immunol. 2013; 13:75-87. [PubMed: 23292121]

99. Bartemes K, Chen CC, Iijima K, Drake L, Kita H. IL-33-Responsive Group 2 Innate Lymphoid Cells Are Regulated by Female Sex Hormones in the Uterus. J Immunol. 2017

100. Monticelli LA, Sonnenberg GF, Abt MC, Alenghat T, Ziegler CG, Doering TA, Angelosanto JM, Laidlaw BJ, Yang CY, Sathaliyawala T, Kubota M, Turner D, Diamond JM, Goldrath AW, Farber DL, Collman RG, Wherry EJ, Artis D. Innate lymphoid cells promote lung-tissue homeostasis after infection with influenza virus. Nat Immunol. 2011; 12:1045-1054. [PubMed: 21946417]

101. Molofsky AB, Nussbaum JC, Liang HE, Van Dyken SJ, Cheng LE, Mohapatra A, Chawla A, Locksley RM. Innate lymphoid type 2 cells sustain visceral adipose tissue eosinophils and alternatively activated macrophages. J Exp Med. 2013; 210:535-549. [PubMed: 23420878]

102. Nussbaum JC, Van Dyken SJ, von Moltke J, Cheng LE, Mohapatra A, Molofsky AB, Thornton EE, Krummel MF, Chawla A, Liang HE, Locksley RM. Type 2 innate lymphoid cells control eosinophil homeostasis. Nature. 2013; 502:245-248. [PubMed: 24037376]

103. Ning F, Liu H, Lash GE. The Role of Decidual Macrophages During Normal and Pathological Pregnancy. Am J Reprod Immunol. 2016; 75:298-309. [PubMed: 26750089]

104. Fuss IJ, Neurath M, Boirivant M, Klein JS, de la Motte C, Strong SA, Fiocchi C, Strober W. Disparate CD4+ lamina propria (LP) lymphokine secretion profiles in inflammatory bowel disease. Crohn's disease LP cells manifest increased secretion of IFN-gamma, whereas ulcerative colitis LP cells manifest increased secretion of IL-5. J Immunol. 1996; 157:1261-1270. [PubMed: 8757634]

105. Fuss IJ, Heller F, Boirivant M, Leon F, Yoshida M, Fichtner-Feigl S, Yang Z, Exley M, Kitani A, Blumberg RS, Mannon P, Strober W. Nonclassical CD1d-restricted NK T cells that produce IL-13 characterize an atypical Th2 response in ulcerative colitis. J Clin Invest. 2004; 113:14901497. [PubMed: 15146247]

106. Edmondson N, Bocking A, Machin G, Rizek R, Watson C, Keating S. The prevalence of chronic deciduitis in cases of preterm labor without clinical chorioamnionitis. Pediatr Dev Pathol. 2009; 12:16-21. [PubMed: 18171100] 
107. Kim CJ, Romero R, Chaemsaithong P, Kim JS. Chronic inflammation of the placenta: definition, classification, pathogenesis, and clinical significance. Am J Obstet Gynecol. 2015; 213:S53-69. [PubMed: 26428503]

108. Satoh-Takayama N, Vosshenrich CA, Lesjean-Pottier S, Sawa S, Lochner M, Rattis F, Mention JJ, Thiam K, Cerf-Bensussan N, Mandelboim O, Eberl G, Di Santo JP. Microbial flora drives interleukin 22 production in intestinal NKp46+ cells that provide innate mucosal immune defense. Immunity. 2008; 29:958-970. [PubMed: 19084435]

109. Luci C, Reynders A, Ivanov II, Cognet C, Chiche L, Chasson L, Hardwigsen J, Anguiano E, Banchereau J, Chaussabel D, Dalod M, Littman DR, Vivier E, Tomasello E. Influence of the transcription factor RORgammat on the development of NKp46+ cell populations in gut and skin. Nat Immunol. 2009; 10:75-82. [PubMed: 19029904]

110. Takatori H, Kanno Y, Watford WT, Tato CM, Weiss G, Ivanov II, Littman DR, O'Shea JJ. Lymphoid tissue inducer-like cells are an innate source of IL-17 and IL-22. J Exp Med. 2009; 206:35-41. [PubMed: 19114665]

111. Cupedo T, Crellin NK, Papazian N, Rombouts EJ, Weijer K, Grogan JL, Fibbe WE, Cornelissen JJ, Spits H. Human fetal lymphoid tissue-inducer cells are interleukin 17-producing precursors to RORC+ CD127+ natural killer-like cells. Nat Immunol. 2009; 10:66-74. [PubMed: 19029905]

112. Sonnenberg GF, Monticelli LA, Alenghat T, Fung TC, Hutnick NA, Kunisawa J, Shibata N, Grunberg S, Sinha R, Zahm AM, Tardif MR, Sathaliyawala T, Kubota M, Farber DL, Collman RG, Shaked A, Fouser LA, Weiner DB, Tessier PA, Friedman JR, Kiyono H, Bushman FD, Chang KM, Artis D. Innate lymphoid cells promote anatomical containment of lymphoidresident commensal bacteria. Science. 2012; 336:1321-1325. [PubMed: 22674331]

113. Hepworth MR, Monticelli LA, Fung TC, Ziegler CG, Grunberg S, Sinha R, Mantegazza AR, Ma HL, Crawford A, Angelosanto JM, Wherry EJ, Koni PA, Bushman FD, Elson CO, Eberl G, Artis D, Sonnenberg GF. Innate lymphoid cells regulate CD4+ T-cell responses to intestinal commensal bacteria. Nature. 2013; 498:113-117. [PubMed: 23698371]

114. Dealtry GB, Clark DE, Sharkey A, Charnock-Jones DS, Smith SK. Expression and localization of the Th2-type cytokine interleukin-13 and its receptor in the placenta during human pregnancy. Am J Reprod Immunol. 1998; 40:283-290. [PubMed: 9784801]

115. Higuma-Myojo S, Sasaki Y, Miyazaki S, Sakai M, Siozaki A, Miwa N, Saito S. Cytokine profile of natural killer cells in early human pregnancy. Am J Reprod Immunol. 2005; 54:21-29. [PubMed: 15948769]

116. Sharma S, Godbole G, Modi D. Decidual Control of Trophoblast Invasion. Am J Reprod Immunol. 2016; 75:341-350. [PubMed: 26755153]

117. Halim TY, Steer CA, Matha L, Gold MJ, Martinez-Gonzalez I, McNagny KM, McKenzie AN, Takei F. Group 2 innate lymphoid cells are critical for the initiation of adaptive T helper 2 cellmediated allergic lung inflammation. Immunity. 2014; 40:425-435. [PubMed: 24613091]

118. Allen JE, Sutherland TE. Host protective roles of type 2 immunity: parasite killing and tissue repair, flip sides of the same coin. Semin Immunol. 2014; 26:329-340. [PubMed: 25028340]

119. Vazquez J, Chavarria M, Li Y, Lopez GE, Stanic AK. Computational flow cytometry analysis reveals a unique immune signature of the human maternal-fetal interface. Am J Reprod Immunol. 2017 
A
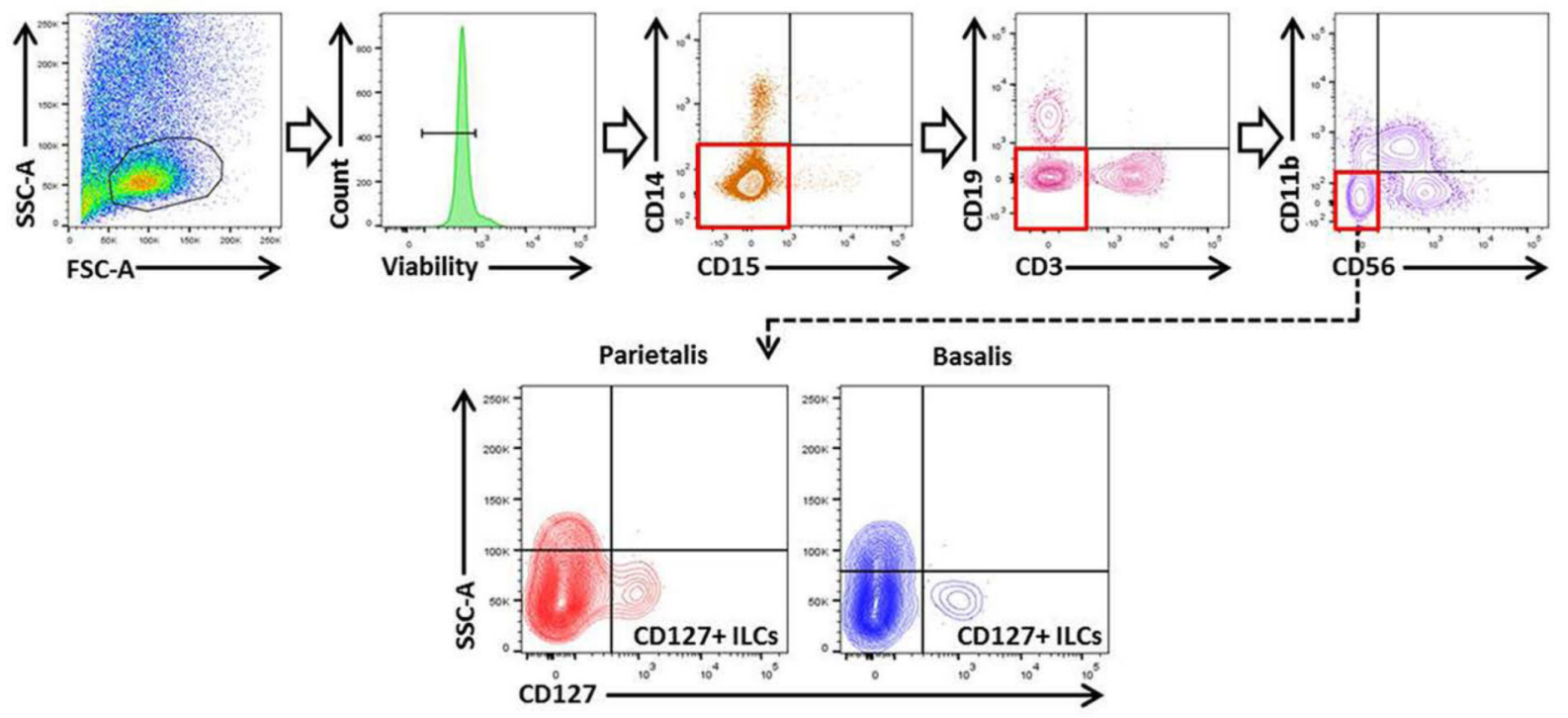

B

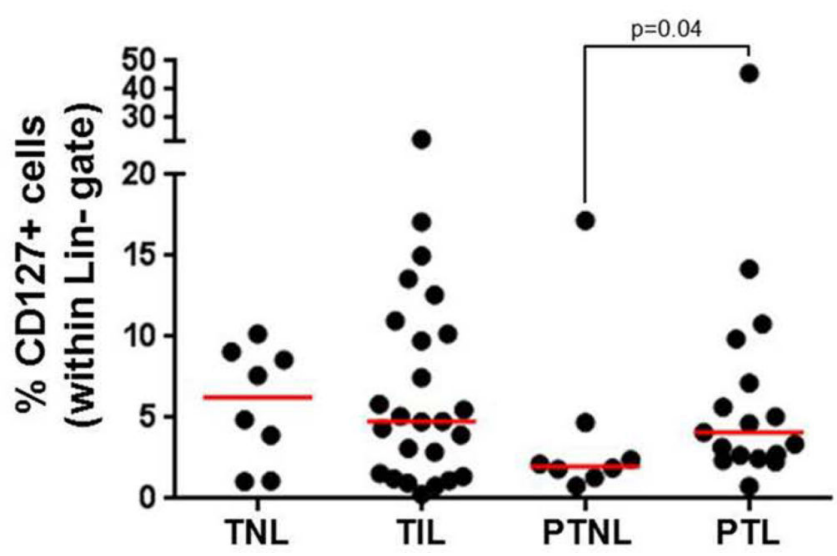

C

Decidua Basalis

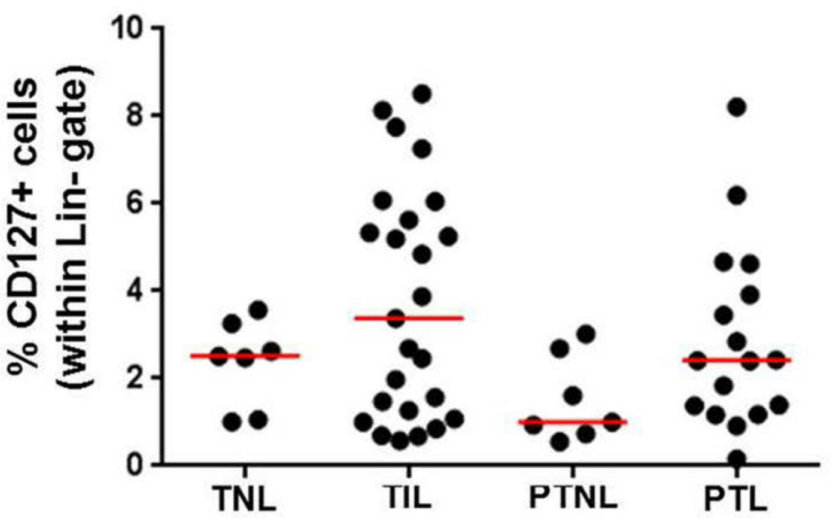

Figure 1.

ILCs are present at the human maternal-fetal interface. (A) Mononuclear cells were isolated from the decidua parietalis and decidua basalis. Flow cytometry gating strategy for immunophenotyping of ILCs. ILCs (CD127+) were initially gated within the viability gate and linage negative (Lin-; CD15-CD14-CD3-CD19-CD56-CD11b-) gate. Red boxes represent the lineage negative populations. Representative flow cytometry contour plots show the expression of CD127 by ILCs from the decidua parietalis and decidua basalis. The proportion of total ILCs in the decidua parietalis (B) and decidua basalis (C) of women who underwent spontaneous preterm (PTL) or term (TIL) labor and those who delivered preterm (PTNL) or term (TNL) without labor. $n=8-25$ per group. 
A

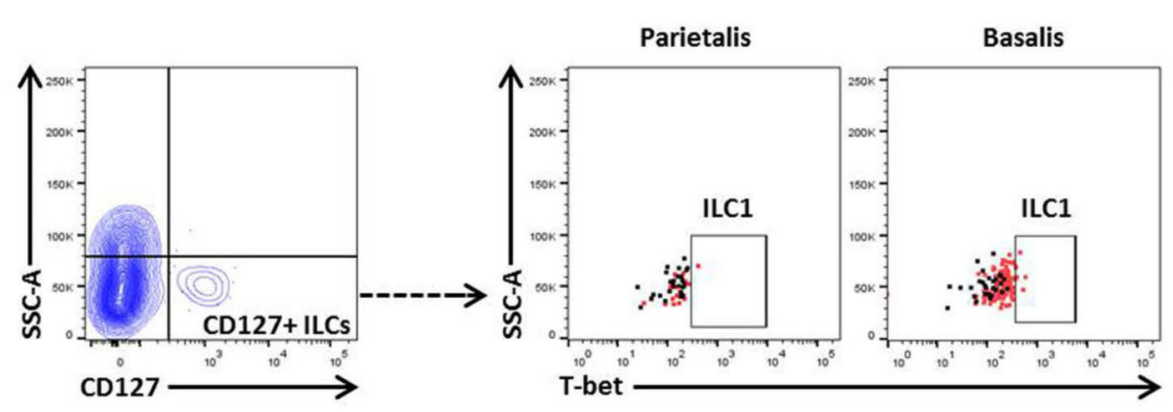

B

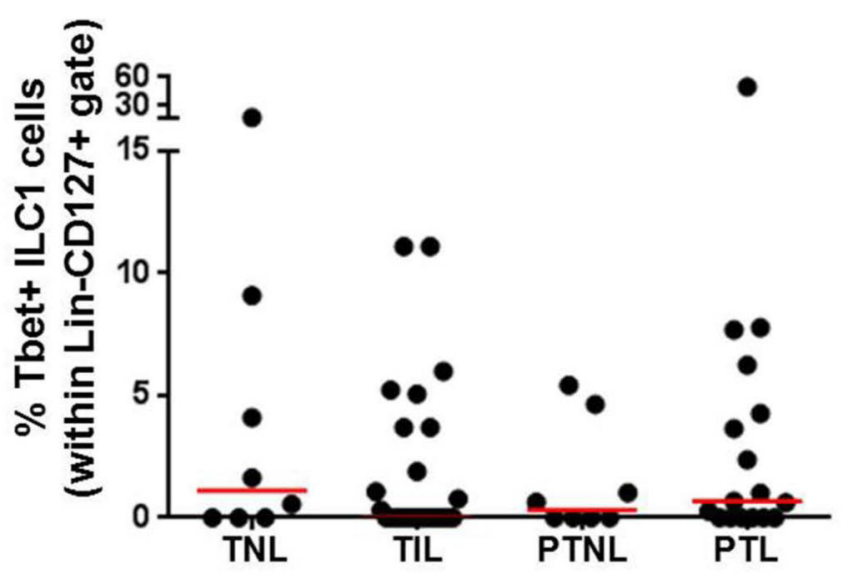

C

Decidua Basalis

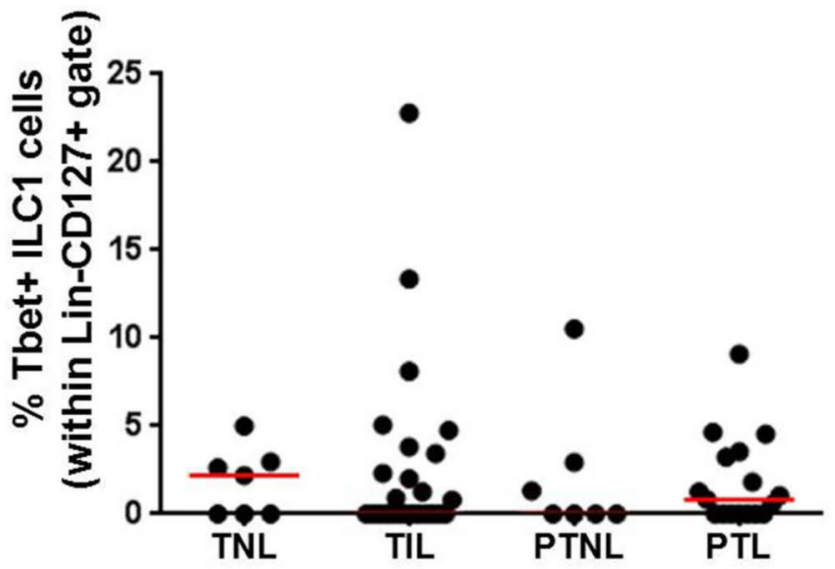

Figure 2.

ILC1s are a minor population in the decidua. (A) Mononuclear cells were isolated from the decidua parietalis and decidua basalis. Flow cytometry gating strategy for immunophenotyping of ILC1s. ILCs (CD127+) were initially gated within the viability gate and linage negative (Lin-; CD15-CD14-CD3-CD19-CD56-CD11b-) gate. Representative flow cytometry contour plots show the expression of T-bet by ILC1s from the decidua parietalis and decidua basalis (red dots). Isotype controls are shown as black dots. The proportion of ILC1s in the decidua parietalis (B) and decidua basalis (C) of women who underwent spontaneous preterm (PTL) or term (TIL) labor and those who delivered preterm (PTNL) or term (TNL) without labor. $n=8-25$ per group. 
A
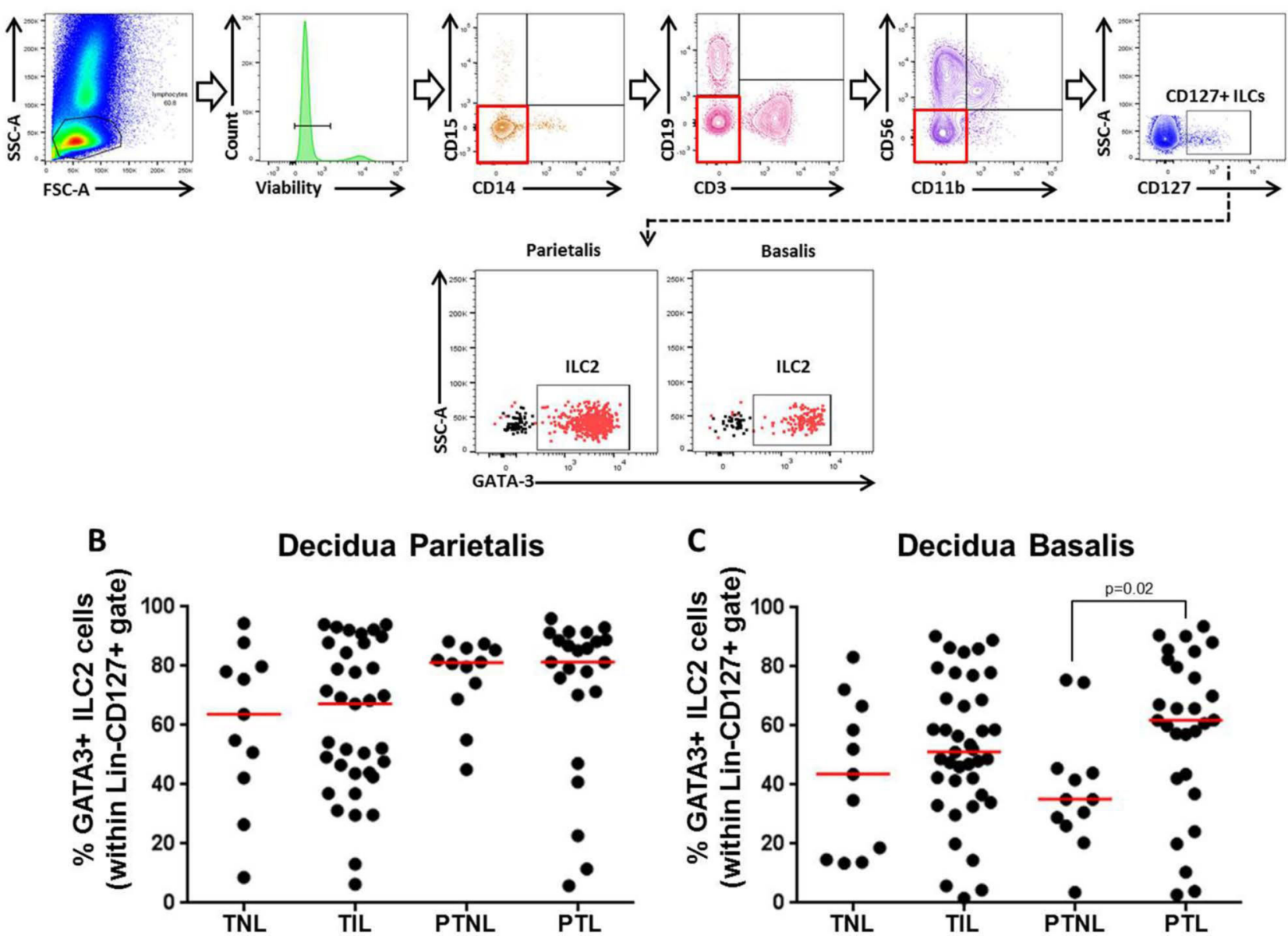

Figure 3.

ILC2s are the most abundant ILC subset in the decidua. (A) Mononuclear cells were isolated from the decidua parietalis and decidua basalis. Flow cytometry gating strategy for immunophenotyping of ILC2s. ILCs (CD127+) were initially gated within the viability gate and the linage negative (Lin-; CD15-CD14-CD3-CD19-CD56-CD11b-) gate. Red boxes represent the lineage negative populations. Representative flow cytometry contour plots show the expression of GATA3 by ILC2s from the decidua parietalis and decidua basalis (red dots). Isotype controls are shown as black dots. The proportion of ILC $2 \mathrm{~s}$ in the decidua parietalis (B) and decidua basalis (C) of women who underwent spontaneous preterm (PTL) or term (TIL) labor and those who delivered preterm (PTNL) or term (TNL) without labor. $\mathrm{n}=11-39$ per group. 
A

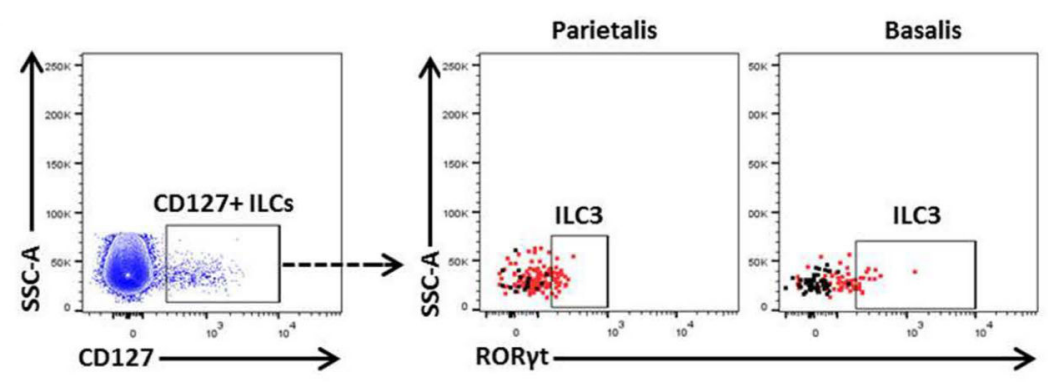

B

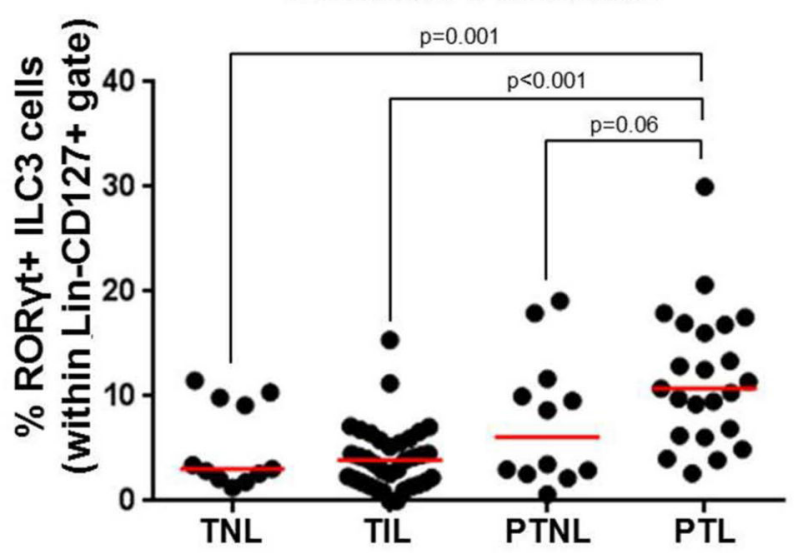

C

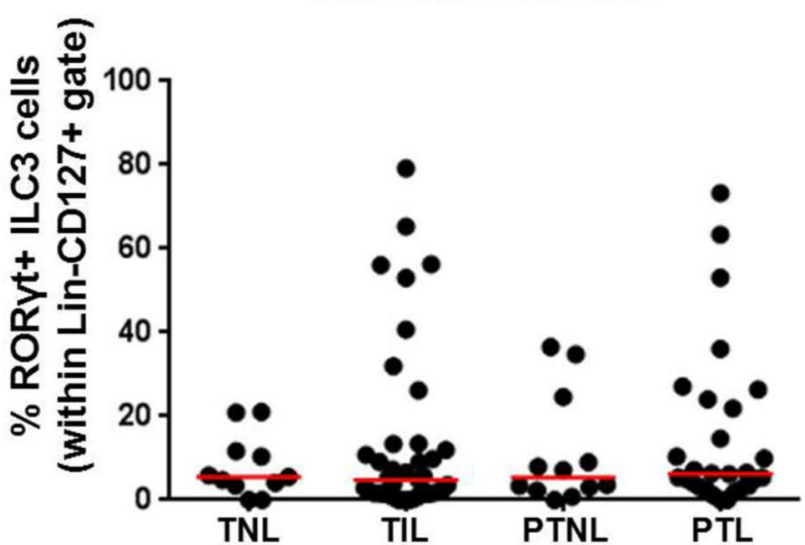

Figure 4.

ILC3s are increased in the decidua parietalis of women who underwent spontaneous preterm labor. (A) Mononuclear cells were isolated from the decidua parietalis and decidua basalis. Flow cytometry gating strategy for immunophenotyping of ILC3s. ILCs (CD127+) were initially gated within the viability gate and linage negative (Lin-;

CD15-CD14-CD3-CD19-CD56-CD11b-) gate. Representative flow cytometry contour plots show the expression of ROR $\gamma \mathrm{t}$ by ILC3s from the decidua parietalis and decidua basalis (red dots). Isotype controls are shown as black dots. The proportion of ILC3s in the decidua parietalis (B) and decidua basalis (C) of women who underwent spontaneous preterm (PTL) or term (TIL) labor and those who delivered preterm (PTNL) or term (TNL) without labor. $n=11-39$ per group. 
A

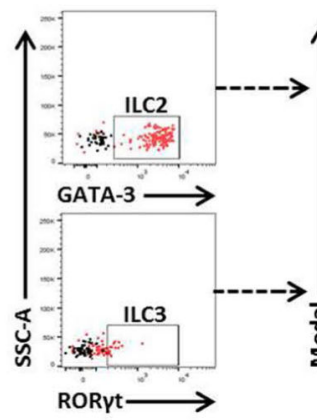

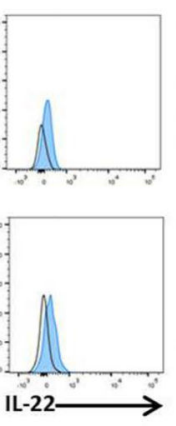
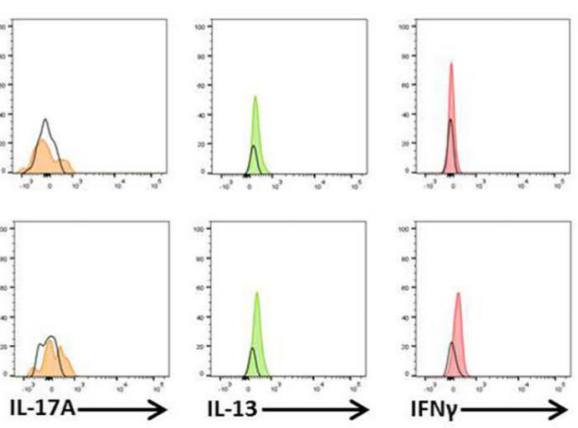

B

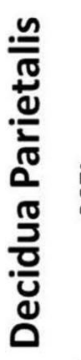

ํㅡㅁ

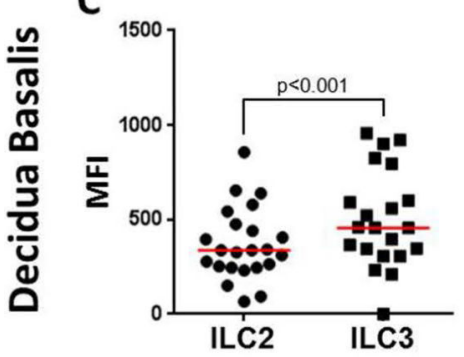

D

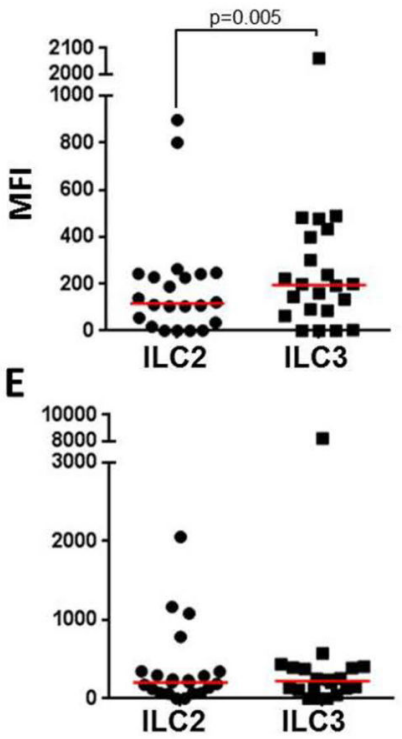

$\mathbf{F}$
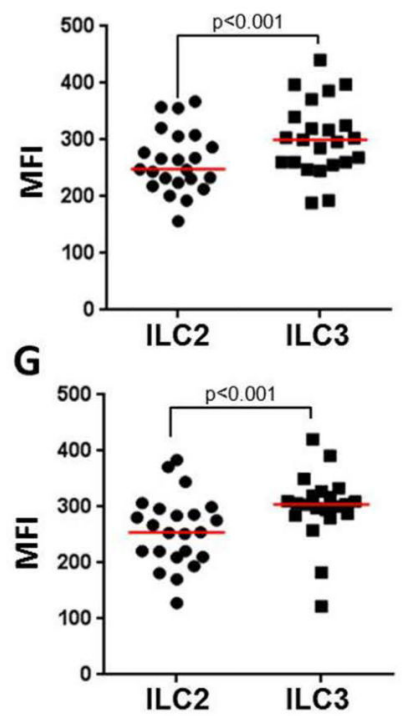

H
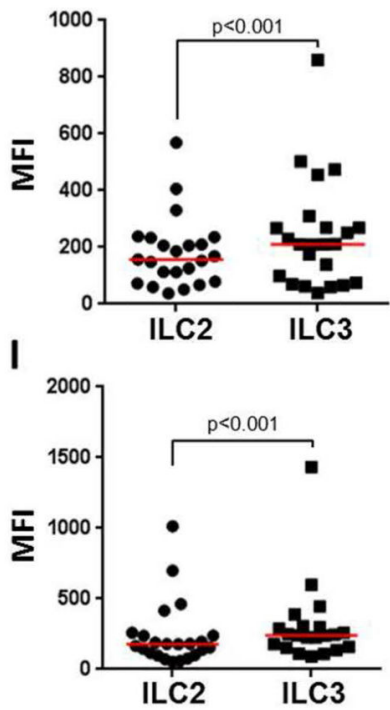

Figure 5.

Decidual ILC3s express IL-13 and IL-22 in women who underwent spontaneous preterm labor. (A) Mononuclear cells were isolated from the decidua parietalis and decidua basalis. Representative flow cytometry histograms show the mean fluorescence intensity (MFI) expression of IFN $\gamma$ (red histograms), IL-13 (green histograms), IL-17A (orange histograms), and IL-22 (blue histograms) by decidual ILC2s and ILC3s (red dots). Isotype controls are shown as black outline histograms or as black dots. The MFI of IFN $\gamma(\mathbf{B} \& \mathbf{F})$, IL-13 (C\&G), IL-17A (D\&H), and IL-22 (E\&I) expression by ILC2s and ILC3s in the decidua parietalis (upper row) and the decidua basalis (bottom row) of women who underwent spontaneous preterm labor. $\mathrm{n}=23$. 


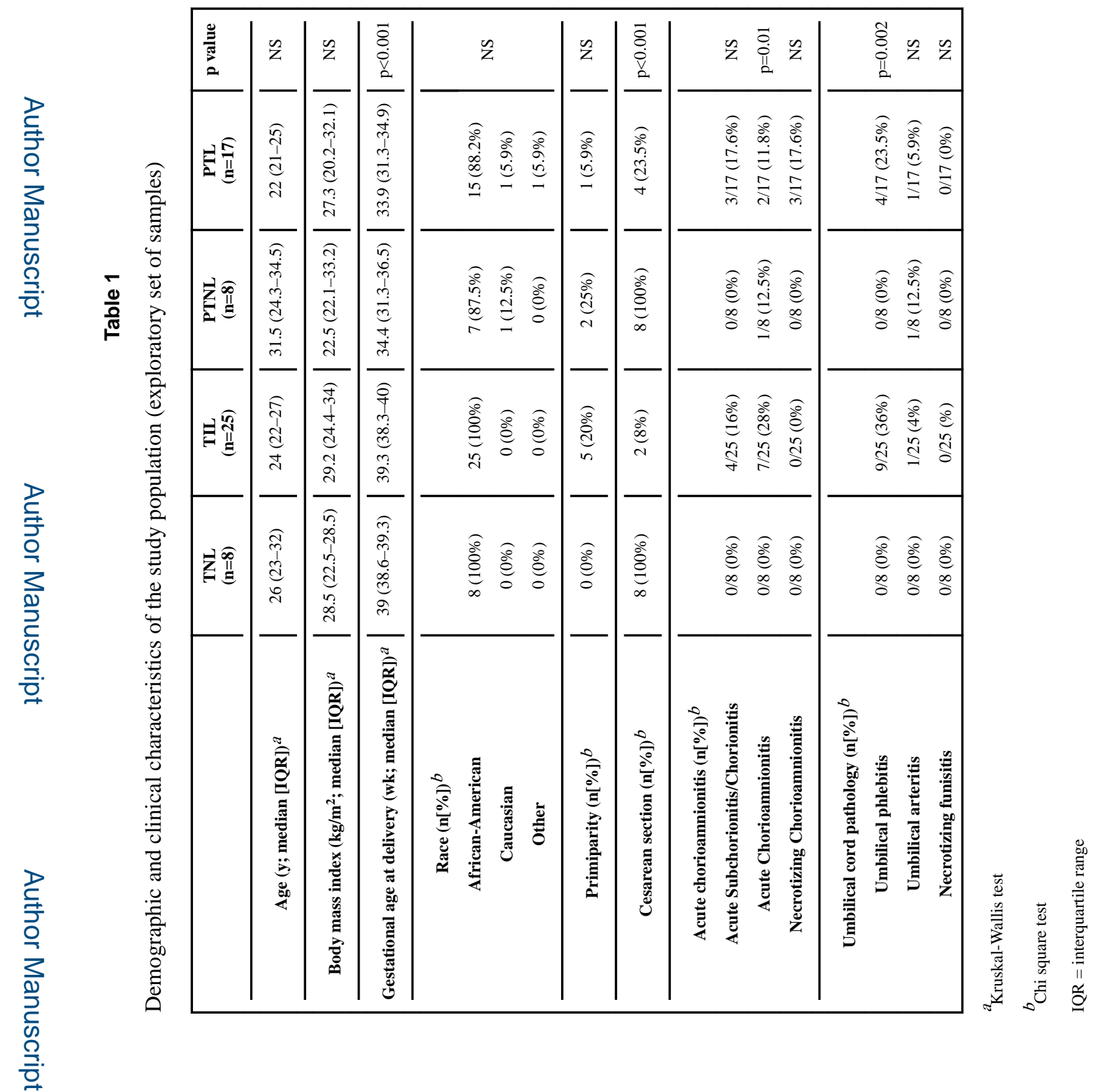

Am J Reprod Immunol. Author manuscript; available in PMC 2019 June 01. 


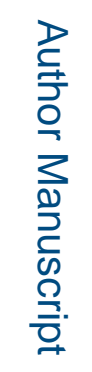

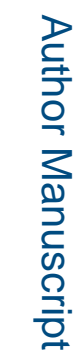

\begin{tabular}{|c|c|c|c|c|c|c|c|c|c|}
\hline 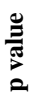 & 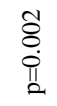 & $\begin{array}{l}\text { oे } \\
\text { i. } \\
\text { il }\end{array}$ & $\begin{array}{l}\vec{\Xi} \\
\dot{0} \\
\dot{\vec{v}} \\
\stackrel{a}{a}\end{array}$ & 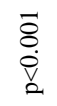 & $\bar{z}$ & $\tilde{z}$ & $\begin{array}{l}\vec{\delta} \\
\dot{0} \\
\dot{0} \\
\stackrel{0}{0}\end{array}$ & $\bar{z} \sum_{z}^{n}$ & 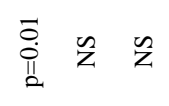 \\
\hline 롱 & 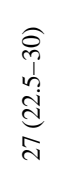 & 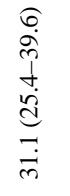 & 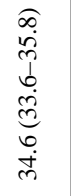 & 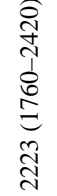 & 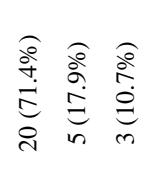 & 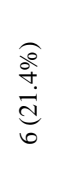 & $\begin{array}{l}\text { बa } \\
\stackrel{0}{\mathrm{~d}} \\
\mathrm{~d}\end{array}$ & 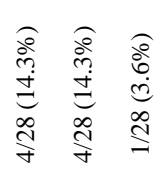 & 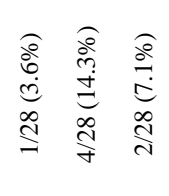 \\
\hline 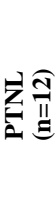 & $\begin{array}{l}\tilde{n} \\
\text { i } \\
0 \\
\infty \\
\stackrel{d}{d} \\
\bar{m}\end{array}$ & 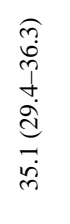 & 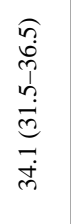 & 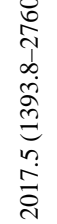 & 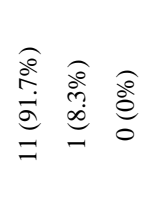 & $\underset{\substack{0 \\
\infty}}{\infty}$ & 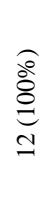 & 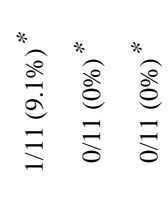 & 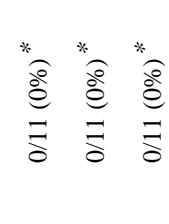 \\
\hline
\end{tabular}

I

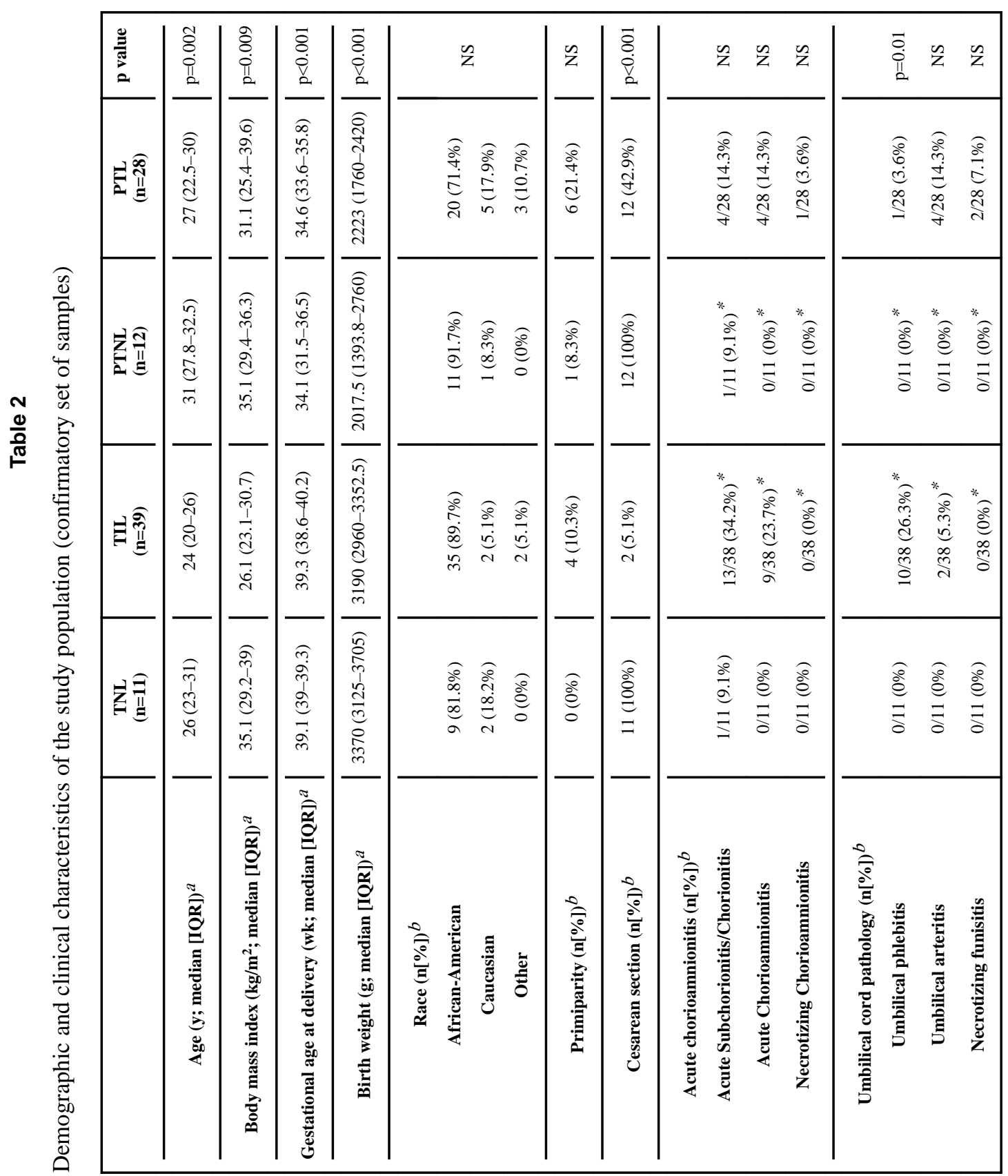

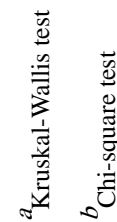

Am J Reprod Immunol. Author manuscript; available in PMC 2019 June 01. 

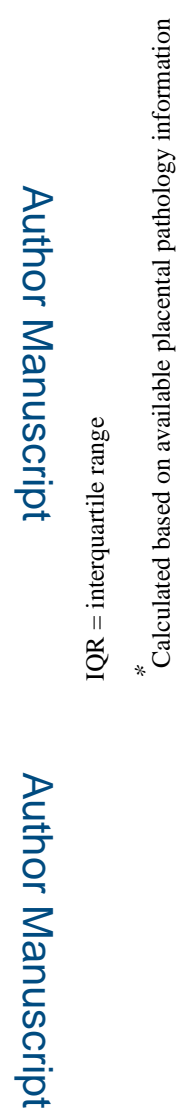

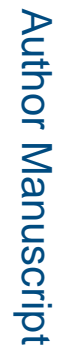

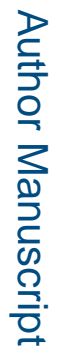

Am J Reprod Immunol. Author manuscript; available in PMC 2019 June 01. 